OPEN ACCESS

Edited by:

Michele Filippo Fontefrancesco,

University of Gastronomic

Sciences, Italy

Reviewed by:

Ragnheidur Bogadóttir,

University of the Faroe Islands,

Faroe Islands

Raivo Kalle

University of Gastronomic

Sciences, Italy

*Correspondence:

Ingvar Svanberg

ingvar.svanberg@ires.uu.se

Specialty section:

This article was submitted to Social Movements, Institutions and

Governance,

a section of the journal

Frontiers in Sustainable Food Systems

Received: 27 August 2020 Accepted: 02 February 2021

Published: 23 February 2021

Citation:

Svanberg I (2021) The Importance of Animal and Marine Fat in the Faroese Cuisine: The Past, Present, and Future of Local Food Knowledge in an Island

Society.

Front. Sustain. Food Syst. 5:599476. doi: 10.3389/fsufs.2021.599476

\section{The Importance of Animal and Marine Fat in the Faroese Cuisine: The Past, Present, and Future of Local Food Knowledge in an Island Society}

\author{
Ingvar Svanberg* \\ Institute for Russian and Eurasian Studies, Uppsala University, Uppsala, Sweden
}

Since ecological and climatic conditions limit the possibilities for cereal production, the old-established Faroese traditional food system is principally based on the utilization of animal protein and fat. The diet of the islanders has thus been adapted to the specific environmental circumstances of the area. Historically, fat has provided a high energy and nutritious food source for the hard-working sheep farmers and fishermen. Fat procured from both land and marine animals has formed a vital part of the local food culture. Apart from the insubstantial amount of butter produced in the Faroe Islands, tallow from sheep, fish fat and liver from codfishes, and the blubber from the long-finned pilot whale, has been widely utilized within the households. During the last century, Faroese diet has changed due to external factors such as closer integration into the world economy, modernization, and improved household economy. Although butter, cheese and other dairy products as well as margarine and vegetable oil are nowadays readily available in the convenience shops and supermarkets, tallow, and whale blubber continue to be part and parcel of many of the islanders' cuisine. Today, however, such products are not primarily consumed for their energy content. Instead, it can be seen as a contemporary and regional expression of appraisal toward Faroese cuisine. Appreciating and consuming local food has become an important part of expressing Faroese cultural identity. The traditional diet therefore links the islanders with their history. However, the preparation of Faroese food products is highly dependent on traditional knowledge of how to extract different types of animal fat and process it into locally made dishes. Thus, the longterm survival of traditional Faroese gastronomy is contingent on the maintenance and continuation of this knowledge.

Keywords: ethnogastronomy, foodways, heritage food, qualitative research, traditional food knowledge

\section{INTRODUCTION}

Marine and terrestrial mammals, seabirds, and fish meet the essential nutritional needs of circumpolar fishermen, herdsmen, and hunters. In fact, among these groups, meat and fat play the most important part of daily food intake (Eidlitz, 1969; O'Keefe, 2000). In the same way as other high altitude Northern European societies, the old-established Faroese traditional food system has until recently been based mainly on animal protein and fat, since ecological and climatic conditions have limited the possibilities for cereal production. The diet has thus been adapted to 
the specific environmental circumstances of this part of the world (Fjellström, 1982; Joensen, 1982, 1987; Johansson, 1994; Kuhnlein and Chan, 2000).

Fat provides a high energy density and has therefore been nutritious food for Faroese hard-working sheep farmers and fishermen (Olsson, 1958). Along with carbohydrates and proteins, fats are one of the three main so-called macronutritiens, which are essential for human survival. In addition to providing energy, fat is essential for the human body in the process of building and repairing cells, as well as in producing hormones and hormone-like substances. The human body also needs fat in order to absorb the fat-soluble vitamins A, D, and E (McElroy and Townsend, 2015) (Figure 1).

Although animal and maritime fat has formed an important part of rural diets in subarctic and boreal northern Europe, fat is a seldom-discussed topic in ethnobiological and food-andculture studies. Within the local Faroese cuisine, animal, and maritime fat formed a vital part of the food culture. Apart from the small amount of butter produced in the Faroe Islands (Claussøn Friis, 1632), tallow from sheep, livers from codfishes, and the blubber from the long-finned pilot whale, Globicephala melas, were widely used within the households. Through various methods, the different fat products could also be preserved and stored for years (Debes, 1673; Panum, 1847; Guðjónsson, 1940; Skylv-Hansen, 1950; Olsson, 1954) (Figures 2, 3).

During the twentieth century, local diet has changed due to external factors such as closer integration into the world economy, modernization, and improved household economy (Joensen, 2015; Sørensen et al., 2018). Although nowadays butter, cheese, and other dairy products, as well as margarine and vegetable oil are readily available in grocery stores and supermarkets, tallow, and whale blubber continue to form part and parcel of many islanders' cuisine (Lauer, 1989). Today however, tallow and blubber are not eaten primarily because of their energy content, but can been seen as appraisal for contemporary Faroese cuisine. Eating Faroese has become an important part in expressing cultural identity (Svanberg, 2015).

Fat can be seen as what ethnobiologists and food-and-culture researchers consider a cultural keystone in the Faroese foodways (Taylor and Anderson, 2020). Local food craft is still important.

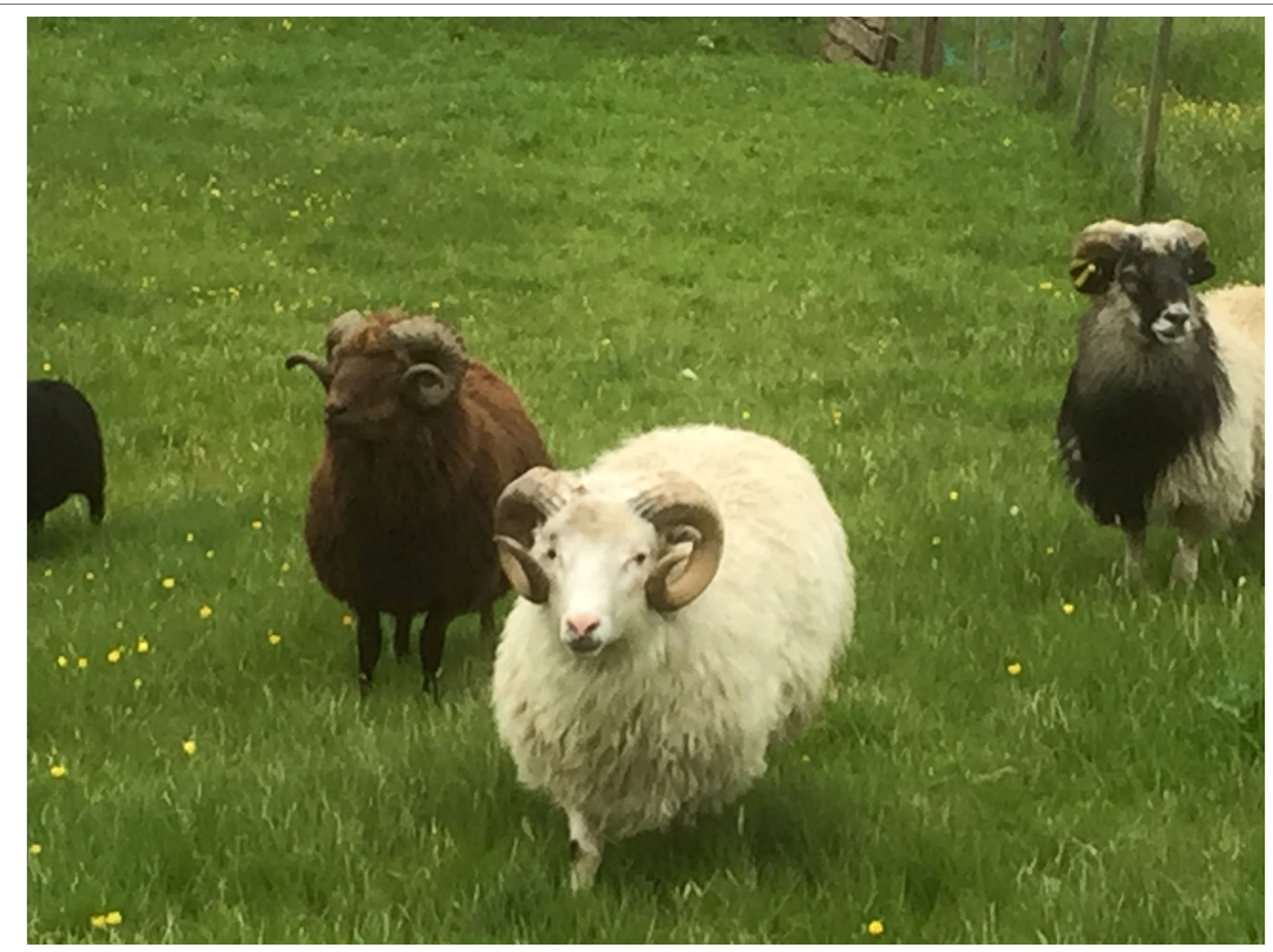

FIGURE 1 | Faroese sheep in Gjógv (Photo Osva Olsen, July 2017). 


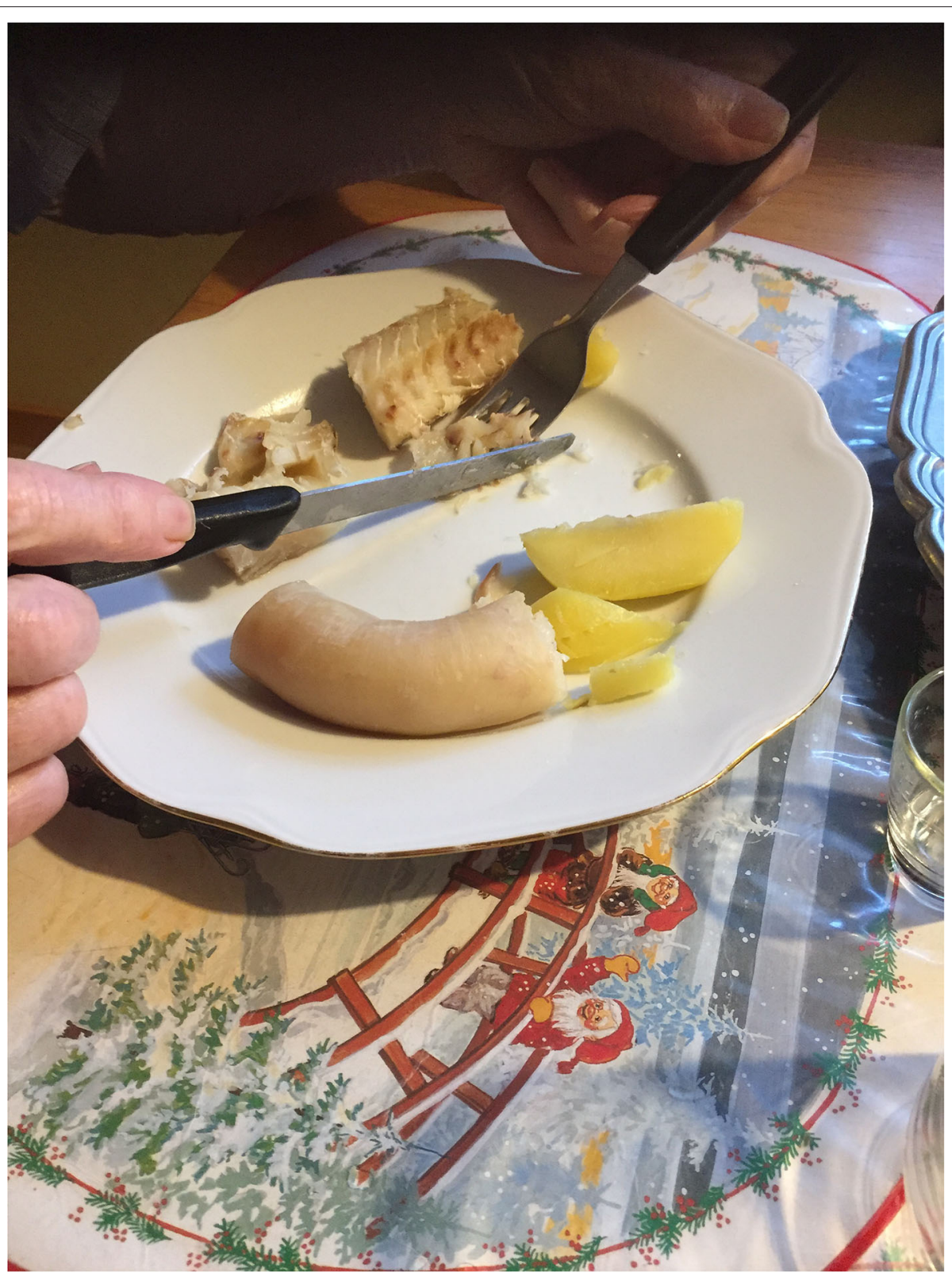

FIGURE 2 | A meal consisting of fermented cod (ræstur fiskur), potatoes and sperðil (made from sheep's rectum filled with tallow). Served as a Christmas meal in Vestmanna in 2018 (Photo Ingvar Svanberg, December 2018).

Nowadays it is considered a question of taste and in-group solidarity to eat locally produced fat products such as fish cakes, fish dumplings, tallow sausage, as spread on sandwich or together with dried or fermented fish, and occasional dried whale meat. Some of these products are now quite expensive, and therefore an increasing number of gastro-tourists arriving to the islands enquire for specific Faroese dishes prepared with locally produced fat. However, as mentioned earlier, the traditional food knowledge is important for the long-term survival of the Faroese cuisine.
The transfer of local or traditional food knowledge within the Faroese society can, following a model by Sydow (1948), be defined as vertical, which means that knowledge about diet and food craft is transferred primarily from individuals belonging to different generations (primarily within the same household). The other kind of food knowledge is transferred horizontally; that is between people of the same age (restaurant kitchen context may serve as an example, as well as TV chefs and cookery books). Nowadays, there are a number of cookery books containing traditional recipes that are widely available (e.g., Dalsgaard, 


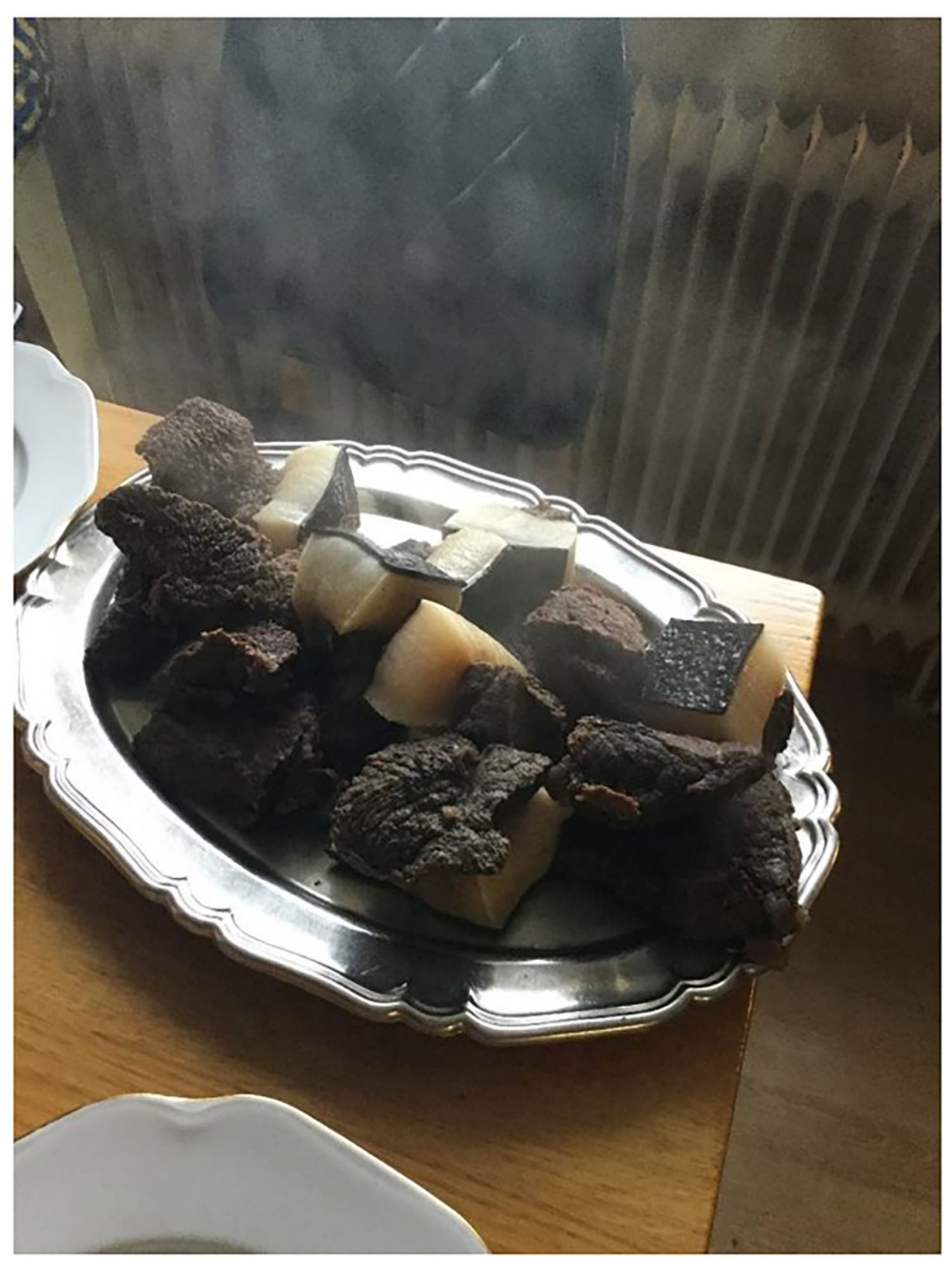

FIGURE 3 | Boiled whale meat and blubber (Photo Ingvar Svanberg).

2002; Henriksen, 2004; Skaale and Johannesen, 2010). Besides the individual bearers of tradition performing the artisan food craft, the consumers within a household contribute as important correctors, although as passive tradition bearers, as Sydow (1948) calls them. They want the food cooked in a certain way, which the person who cooks has to comply with (for instance seasoning, cooking time, and side dishes). Within established households, there are often conservative structures. The food should taste, as it has always done ("mom's cooking is the best"). Especially men who spend months on commercial fishing vessels, want the conditions to be "as it used to be" when returning home. As a result, they have a strong preference for local, traditional food (Svanberg, 2015).

\section{FRAMEWORK AND RESEARCH AIMS}

Several researchers have emphasized the continuity of the Faroese foodways. The main purpose of this chapter is thus to discuss why fat from terrestrial and marine mammals, seabirds, and fish have played such an important role in the Faroese diet ever since the first settlers arrived to the Faroe Islands. For instance, when the food-and-culture researcher Alfa Olsson in the 1950s compared 
the western Nordic peasantry diets, she discovered with regard to the Faroe Islands that the dietary habits of the islanders seemed particularly well-preserved there and displayed strong continuity with bygone days (Olsson, 1958).

Her fieldwork in the Faroes took place in 1952 and consisted in observation and interviews about local food habits (Olsson, 1952). Her conclusions were largely correct, since at that time the fishing and farming households of the Faroe Islands were still rather self-sufficient when it came to staple foods such as fresh, fermented, and processed animal products (Håseth et al., 2015). Still in the mid-1990s, I could observe this subsistence pattern in many rural households. Many dishes that she describes are interesting examples of cultural persistence on the islands (Olsson, 1954). Knetti, for instance, is a kind of large fish ball containing lumps of lamb's tallow, grunningshøvd, are heads of cod fermented in the open air, while sperðil is a sheep's rectum filled with tallow or suet (Svabo, 1966; Nyman, 1984; Svanberg, 2015).

These are illustrative examples of ancient heritage food that have survived since the Viking age. Until recently, most people on the islands mastered the craft of producing food from slaughtered animals (including whales) and freshly caught fish (Joensen, 2009 , 2015). Even today, especially the elderly generation, has continued consuming a rural diet mainly based on fish and meat products. This segment of the population possess the traditional knowledge of preparing and utilizing meat, fat, and offal, and know how to preserve meat and fish by traditional methods of drying, fermentation, and salting. For them, products such as tallow and whale blubber are also cherished side dishes of importance for them since the flavors correspond to what they have grown accustomed to since childhood. With the exception of potatoes, onions and carrots, vegetables play an insignificant role in their daily diet (Dalgård et al., 2010; Svanberg, 2015).

However, several studies of Faroese food habits and food changes have documented the dichotomization between socalled market foods and traditional foodstuffs. Nowadays, convenience food usually provides a greater proportion of daily consumption (Rasmussen, 1971; Lauer, 1989; Joensen, 2015). In everyday language, many locals make a distinction between føroyskur matur "Faroese food" (based on locally available resources) and útlendskur matur "foreign food" (e.g., pasta, rice, and other imported foodstuff). Nevertheless, traditional Faroese food still constitutes an important part of local eating habits (Joensen, 2015; Svanberg, 2015).

Within food-and-culture studies, we can distinguish between diet, i.e., the food people consume, subsistence, i.e., the way in which the provisions are acquired, including the technologies involved in both capture and preparation, and foodways, i.e., the entire set of activities, symbolism, and beliefs surrounding the acquisition, preparation, and serving of food (Schulting, 2018). Due to the ecological conditions and geographical situation, the Faroese diet and subsistence were very much the same until the early twentieth century (Joensen, 2015), although there have been some important turning points due to external factors (Teuteberg, 1986).
This chapter attempts to examine the historical and contemporary importance of animal and marine fat in the local Faroese diet, including its production, preparation, and place in the local and national cuisine of the Faroes. The chapter will also discuss such factors as commensality, gastro-tourism, and changes in local attitudes toward fats used as food, since they all are aspects that I have found relevant in this context. Regarding the production and consumption of most of the dishes mentioned in the text, empirical data has been collected from a wide range of historical sources as well as my own observations on Faroese foodways. Therefore, this study can be characterized as a diachronic analysis of the importance of fat in the Faroese diet (cf. Jönsson, 2020).

As an ethnobiologist with an anthropological background, I find it difficult to use the term traditional, as it can be perceived as contradictory to change (Peloquin and Berkes, 2009). Of course, the knowledge of the food is constantly changing, but I accept the concept traditional food knowledge for this chapter. However, we must remember that food culture, as every kind of culture, is something that is alive and constantly changes and it contains an active element. As Swedish ethnologist Jönsson reminds us, food culture does not exist; it is created and re-created (Jönsson, 2020). Local or traditional food knowledge is fundamental for maintaining dietary continuity and food culture. There is an interesting strain of cultural persistence when it comes to local food habits, which includes aspects such as food craft, availability of locally produced natural material, traditions, and taste, but also the concept of Faroese national identity (Svanberg, 2015).

\section{MATERIALS AND METHODS}

In this chapter, I have used ethnographic qualitative methods and perspectives from ethnobiology and nutritional anthropology (Anderson, 2014; Pieroni et al., 2016). The data has been gathered through ethnographic fieldwork (including participant observations), as well as from written historical sources.

\section{Environmental and Social Setting}

The Faroe Islands consists of 17 populated (out of 18) rocky islands and numerous islets, with a dramatic nature and a rich bird life. The landscape is treeless and mountainous. The climate is subpolar oceanic influenced by the North Atlantic Current. Winters are mild and summers cold. It is windy and rainy (Joensen, 1982; Hannon et al., 2009). The islands are located in the Atlantic Ocean, between Iceland, Norway, and Scotland. The area constitutes 1,399 square kilometers, and the total population is 52,920 inhabitants (December, 2020). About 40 per cent live in the capital, Tórshavn. The majority of the population is ethnic Faroe islanders who as their mother tongue speak the Faroese language (Hagstova Føroya, 2021). However, most of the Faroese people are bilingual and speak and understand Danish as well (Knudsen, 2010).

Present-day Faroese society is a late-modern high-tech welfare state. The Faroe Islands' primary economic activity is commercial fishing. Today the fishing industry covers a wide range of activities spanning both pelagic and demersal fisheries in Faroese 
and more distant fishing waters. In addition, there is a large fish processing industry. Besides this, salmon farming on the Faroes is also one of the most profitable aquaculture industries in the world. The recent economic growth has also created new jobs in the service industries for people with university degrees. Earlier the Faroe Islands did not have as much opportunity for welleducated people as it does now. In 2019, the Faroe Islands were the fastest growing country in the Nordic Region. At present, Faroese society is experiencing rapid changes at the same pace as other post-industrial countries. Changes can be attributed to a number of reasons such as globalization, infrastructural initiatives, and economic growth. Undoubtedly, such factors will have an impact on the lifestyle and consumption pattern of the inhabitants. Some of these changes can already be observed. For instance, today formerly important economic activities such as hunting and sheep farming are mainly conducted on a hobby basis (Joensen, 2020; Hagstova Føroya, 2021; Svanberg, in press).

Total life expectancy (both sexes) at birth for Faroe Islands is 82.6 years (Hagstova Føroya, 2021). Still, in contrast to other European countries, the rate of crime is exceptionally small (Svanberg, in press). Culturally, the Faroe Islands comprise a small and relatively homogenous society. Although archaeological research has produced strong archaeological indications of a human colonization of the Faroe Islands between AD 400 - 600 (Church et al., 2013), the current inhabitants are descendants of Viking Norsemen that arrived in the ninth century (Arge, 2014). In 1523, the islands became part of Denmark. The population is mostly Lutheran, belonging to the Faroese Lutheran Church (80\%). The remainder belongs to the Open Plymouth Brethren and various charismatic movements. Compared to other Nordic countries, it is a rather conservative Christian nation (Larsson and Svanberg, 2009).

\section{Fieldwork}

Since the mid-1990s, I have on a yearly basis collected field data through participant observations (c.f. Svanberg, 2015). The interviews with informants have been unstructured and conducted according to the generative method, which is based on the respondents' own point of view (Adams et al., 2014; Jönsson, 2020). By using these methods, my objective has been to record local knowledge about Faroese diet, subsistence, and foodways. The interviews took place mainly in Vestmanna, Gjógv, and Tórshavn (the capital of the islands), although I have visited most islands and many villages since 1994 . Through the observation method, I learned about the activities connected with food as well as local knowledge about the environment of the people in their natural setting (Kawulich, 2005). In addition, as an observer, I was introduced to various activities within the human food chain, from fishing and slaughtering to cooking and consuming. I have experienced most of the dishes mentioned in this text and taken part in the making of them (Svanberg, 2015).

Historical data on diet, subsistence, and foodways were found in sources such as in ethnographic reports, archeological studies, travelogues, and local historic accounts. The historical review is important for our understanding of the past and present use of animal and marine fat in the Faroese foodways (Joensen, 1987).

\section{RESULTS}

\section{Traditional Faroese Diet and Subsistence}

Food resources have always been collected from the land as well as from the sea. Traditional homemade Faroese food is mainly made from lamb, sea fish, seabirds, and whale meat. Tallow and whale blubber are also part of the local diet, both as ingredients and as side dishes. These provisions have traditionally been acquired through hunting, fishing, and animal husbandry; subsistence activities that still are important on the Faroe Islands. The most important domestic animals providing local food for humans are sheep, geese, ducks, and cattle. There exists local breeds adapted to the climate and ecological conditions. Among these, sheep are the most important species (Joensen, 1982, 2020; Hannon et al., 2009).

Thanks to recent archaeological research, we have some information about the diet in the post-classic era, from the so-called "landnam period" (Norse period), when the Viking ancestors of the contemporary Faroese people settled on the islands, until the Reformation. Until the late nineteenth century, the islands can be described as a peasant society highly dependent on shepherding although hunting was also carried out (Joensen, 1987). The early settlers brought domestic animals such as sheep and pigs, but also horses and cattle (Arge et al., 2009). Fish, seabirds, and marine mammals were important elements of the local diet (Arge, 2014). While pig breeding ceased already in the thirteenth century, keeping sheep has continued to the present day to be of major importance for the islanders (Arge, 2005). A Royal Decree from 1298, known as the Sheep Letter (Seyðabrovið), deals with sheep husbandry (Young, 1979). According to this ancient decree, the islanders are allowed to keep 70,000 adult sheep during summer season. Noteworthy is that the figure in question has remained virtually unchanged since 1298. In fact, a greater number would lead to overgrazing with the subsequent risk of soil erosion (Stoklund, 1984). About 40,000 sheep are slaughtered each year. Thus, we may observe that the Faroese local diet and food system has a tradition of more than 1000 years (Joensen, 1979, 1987).

Until the end of the nineteenth century, the Faroe Islands can be described as a rather static, isolated and self-sustained peasant society where meat, fat, and fish were by far the most common food products. An interesting "culinary" institution was the socalled tálgardíki "tallow bog," were the farmers stored kneaded tallow obtained from sheep (Olsson, 1952; Joensen, 2015). The presence of these tallow bogs locally serve as a vivid indication of the importance given to fat as an energy source in the Faroes. The longer the tallow was stored in the bog "being so much the better," wrote Lucas Debes in 1673. Each farm had their own bog where they stored kneaded tallow. It served as a sort of measurement of a specific household's prosperity (Debes, 1673). The small amount of butter produced from cattle was exported to Denmark, while the locals preferred marine fat and tallow for their own consumption (Joensen, 1987).

Since human settlement until the early twentieth century sheep husbandry (for meat, tallow, and wool production) and some barley cultivation, hunting for seabirds, and occasionally marine mammals, such as long-finned pilot whale (Globicephala 
melas) and gray seal (Halichoerus grypus), constituted the main base of the economy. Fishing from the shore was carried primarily with the purpose of supplying food for individual households. Only landowning farmers had one or more boat (Joensen, 1987). Fermented fish (e.g., rostur fiskur), made from Atlantic cod (Gadus morhua), saithe (Pollachius virens), or haddock (Melanogrammus aeglefinus), was used as a storable protein source consumed during periods when weather conditions and seasonal fluctuations may affect food availability negatively (Svanberg, 2015).

In the Faroe Islands, the pilot whales have always played an important nutritional role since they have provided people with meat (tvøst) as well as blubber (spik) (Debes, 1673; Panum, 1847; Svabo, 1959; Bloch et al., 2003). An English observer wrote in December 1852 from the village Vestmanna that had it not been for the abundance of captured pilot whales, which made up for the shortage of other food, people would have been at jeopardy (Trevelyan, 1853). Still today, although not as important as before, Faroe islanders continue consuming products (meat, blubber) produced from pilot whales (Bloch et al., 2003; Joensen, 2009). According to Faroese law, it is allowed to take other smaller whales. Occasionally, various dolphins are hunted, earlier also gray seal (Halichoerus grypus). They also provide edible blubber (Joensen, 1987; Bloch et al., 2003; Bloch and Mikkelsen, 2009).

Regarding seabirds, they breed in large numbers on the steep cliffs. For centuries, guillemots (Uria aalge), puffins (Fratercula arctica), black guillemot (Cepphus grille), kittiwakes (Rissa tridactyla), Manx shearwater (Puffinus puffinus), and other bird species have been exploited as food (both meat and eggs) (Claussøn Friis, 1632; Debes, 1673; Svabo, 1959; Svanberg and Ægisson, 2006). In recent years many species have decreased in number and for this reason they are not hunted anymore (Nørrevang, 1986; Svanberg, 2001). However, it should be noted, one species is hunted in great numbers. The bird we are speaking of is the northern fulmar (Fulmarus glacialis), eaten oven-baked and very greasy. This species started colonizing the islands in the first half of the nineteenth century and starting in the 1860s it has been hunted ever since. From 1930 to 1938, cases of human chlamydophilosis were reported from the Faroes. After the outbreaks in the 1930s, hunting fulmars for human consumption was prohibited until 1954 (Hermann et al., 2006). Nowadays the islands is home to a huge population of northern fulmar. Only the recently fledged juveniles leaving their nests on the cliffs are captured. About 100,000-150,000 birds are killed each fall, and provide a significant contribution to the households' diet. It is a very greasy food (Wang et al., 2020).

Historically, all animal foodstuffs had to be preserved by means of various methods. Drying and fermentation have always been important. Curing was introduced later (Joensen, 2015). Much of the flavor and taste, typical for the Faroese food, depends on the traditional preservation methods used, especially fermentation and drying of meat (whale meat, mutton, seabirds) and fish, for instance reest kjøt and reestur fiskur (Joensen, 2015; Svanberg, 2015).

Although some barley (Hordeum vulgare and Hordeum distichon) has been cultivated in the infields, i.e., the more fertile land area close to the farms, on the Faroes since the Viking age (Arge, 2014), the harvests had always been small (Rasmussen, 1957; Joensen, 1987; Guttesen, 2001). This is also reflected in local food habits. Barley flour was used for baking a primitive kind of bread called drýlur, which was prepared in an open peat fire (Joensen, 1987). Usually it was mixed with fat or was put in a soup made of animal stuff. While porridge and bread have been important foods among cereal producing farmers in other parts of northern Europe (Fjellström, 1982; Johansson, 1994), this has not been the case among the Faroe islanders (Joensen, 1987). Instead, the Faroe islanders have prepared dishes of thicker consistency, in which animal fat, liver, and fish roe have played an important role. Blood sausage has also been important in the local diet (Olsson, 1954, Olsson, 1958; Joensen, 2015). The main part of the cultivated land on the Faroes has always been toiled for the production of hay, which has been given to sheep and cattle during the winter season (Nyman, 1958; Svanberg, 1998). Hay is the only crop that remains important today and is used for fodder production (Hannon et al., 2009).

Regarding vegetables in the local diet, traditionally, the root vegetables Faroese turnips (Brassica napus) and Norwegian turnips (Brassica rapa) have been cultivated. It was not until the mid-nineteenth century that potatoes became widely accepted as food in the Faroes (Svanberg, 1998). The sources inform us that as late as the latter part of the nineteenth century, some elderly people refused to consume potatoes (Joensen, 1987). However, with an increasing population and more people getting access to the outfields for growing potatoes, this crop became popularized. In the first decades of the twentieth century, potatoes became very important in Faroese households and dinner was not considered dinner unless it included potatoes (Guttesen, 2001; Joensen, 2015). Garden angelica (Angelica archangelica), was kept in some gardens in olden times, but was regarded as a kind of candy (Svanberg, 1998). In the twentieth century garden culture, promoted by various officials, with culinary rhubarb (Rheum $\times$ hybridum), and some hardy garden shrubs grown for their berries (Ribes uva-crispa, R. nigrum, and R. rubrum) has developed. Apart from the above examples, vegetables has otherwise played an insignificant role in the islanders' diet (Svanberg and Ægisson, 2012; Sørensen et al., 2018). Seaweeds were in times of need used as food (Panum, 1847; Svabo, 1959; Svanberg, 1998).

Important turning points in the Faroese food habits have been influenced by a number of macro-economic factors such as the implementation of free trade and fishing, industrialization and market economy. The introduction of general merchant stores in the larger villages at the turn of the twentieth century was yet an important factor. In these stores the rural people could easier than before come across a large range of products such as flour, sugar, margarine, tea, coffee, and some spices (Joensen, 1987). The introduction of the freezer boxes in the 1960s brought about major changes in the subsistence pattern and foodways (Joensen, 2015).

During the twentieth century, the economy of the Faroes gradually changed from shepherding and subsistence coastal fishery to large-scale deep-sea fishery in the North Atlantic. During World War II, the islands were occupied by British troops. The presence of British soldiers did have some cultural 
TABLE 1 | Main sources of animal and marine fat.

\begin{tabular}{|c|c|c|c|}
\hline Scientific name & English name & Used for & Faroese name \\
\hline \multicolumn{4}{|l|}{ Marine mammals } \\
\hline $\begin{array}{l}\text { Globicephala melas (Traill, } \\
\text { 1809) }\end{array}$ & Long-finned pilot whale & Blubber used as food & grindahvalur \\
\hline $\begin{array}{l}\text { Tursiops truncatus } \\
\text { (Montagu, 1821) }\end{array}$ & Atlantic bottlenose dolphin & Blubber used as food & hvessinug \\
\hline $\begin{array}{l}\text { Lagenorhynchus acutus } \\
\text { (Gray, 1828) }\end{array}$ & White-sided dolphin & Blubber used as food & Springare, skjórutur springare \\
\hline $\begin{array}{l}\text { Lagenorhynchus albirostris } \\
\text { (Gray, 1846) }\end{array}$ & White.beaked dolphin & Blubber used as food & Springare, kjafthvítur springare \\
\hline $\begin{array}{l}\text { Phocoena phocoena (L., } \\
\text { 1758) }\end{array}$ & Harbor porpoise & $\begin{array}{l}\text { Blubber used as grease and food } \\
\text { (historical uses) }\end{array}$ & nísa \\
\hline $\begin{array}{l}\text { Hyperoodon ampellatus } \\
\text { (Forster, 1777) }\end{array}$ & Northern bottlenose whale & $\begin{array}{l}\text { Locally used on Suðuroy: an oil is } \\
\text { extracted from the blubber and used as } \\
\text { external treatment (it is not eaten) }\end{array}$ & døglingur \\
\hline $\begin{array}{l}\text { Halichoers grypus } \\
\text { (Fabricius, 1791) }\end{array}$ & Gray seal & $\begin{array}{l}\text { Blubber used as food, medicine (historical } \\
\text { uses) }\end{array}$ & Kópur, láturkópur \\
\hline \multicolumn{4}{|l|}{ Terrestrial mammals } \\
\hline Bos taurus L., 1758 & Domestic cattle & $\begin{array}{l}\text { Milk for butter, cheese and various diary } \\
\text { products }\end{array}$ & neyt, kýr \\
\hline Ovis aries, L., 1758 & Faroese sheep & $\begin{array}{l}\text { Suet and tallow used as side-dish or as fat } \\
\text { in various kind of food, blood used for } \\
\text { pancakes and black pudding }\end{array}$ & seyður \\
\hline \multicolumn{4}{|l|}{ Sea fowl } \\
\hline $\begin{array}{l}\text { Puffinus puffinus (Brünnich, } \\
\text { 1764) }\end{array}$ & Manx shearwater & Edible fat & skrapur \\
\hline Fulmarus glacialis (L., 1761) & Northern fulmar & Edible fat & havhestur, náti \\
\hline \multicolumn{4}{|l|}{ Fish } \\
\hline Gadus morhua L, 1758 & Atlantic cod & Liver as food and medicine & fiskur, toskur \\
\hline Pollachius virens (L. 1758) & Saithe, Coalfish & Liver as food & Upsi, seiður \\
\hline $\begin{array}{l}\text { Melanogrammus aeglefinus } \\
\text { (L.) }\end{array}$ & Haddock & Liver as food & hýsa \\
\hline
\end{tabular}

Joensen (1987, 2015), Bloch et al. (2003), Bloch and Mikkelsen (2009), Svanberg (2015), field notes 1994-2019.

impact on the islanders, e.g., greeting manners and some food habits, such as British-style chocolate and fish-and-chips (Joensen, 2015; Svanberg, 2015).

\section{Artisan Food Craft and Foodways}

Today, fishing is the primary economic activity. The Faroe Islands has a large fleet of trawlers and smaller line fishing boats, fish factories and fish farms. Although most fish is caught by these larger fishing vessels, some people, primarily men, continue to fish for pleasure and for their own consumption in locally constructed boats that are well-adapted to the surrounding sea conditions (Svanberg, in press). Fish products such as knetti is a Faroese type of homemade dumpling, which is made with minced fish and tallow. Frikadellur on the other hand is a kind of fishcake consisting of fileted fish ground that is mixed with flour and tallow, and finally fried (Olsson, 1954; Nyman, 1984). To make rostur fiskur, fermented cod, is still considered important. Fishermen still dry cod on their ships (Svanberg, 2015). Some very ancient dishes have survived locally, but are becoming increasingly rare (Arge, 1995). Sheep liver filled with tallow is fried, while offal can be minced with fish meat and made into mørknetti (Olsson, 1954). In the Faroe Islands, many people still live in villages, while others have a connection with the villages through their relatives. As a result, they enjoy access to slaughtered lamb products. Besides dry and fermented mutton, they have access to tallow and intestines (Joensen, 1979).

Due to factors such as globalization, infrastructural initiatives, and economic growth, Faroese society is experiencing rapid social change at the same pace as other post-industrial countries. In the end, this will most likely lead to a change in the mentality and lifestyle of the inhabitants. We may for example observe that today post-industrialized diets are quite varied among urban and urbanized people in the Faroe Islands. The society has been characterized and dominated by a long history of monoculture, but this is now changing due to increasing globalization (Joensen, 1987, 2020; Svanberg, 2015).

Export of fish and fish products is the dominating industry, providing welfare to the country. Thus, we can see that the modern economy is highly dependent on fishing and fish farming. Although experiencing a setback in 2020 due to the 


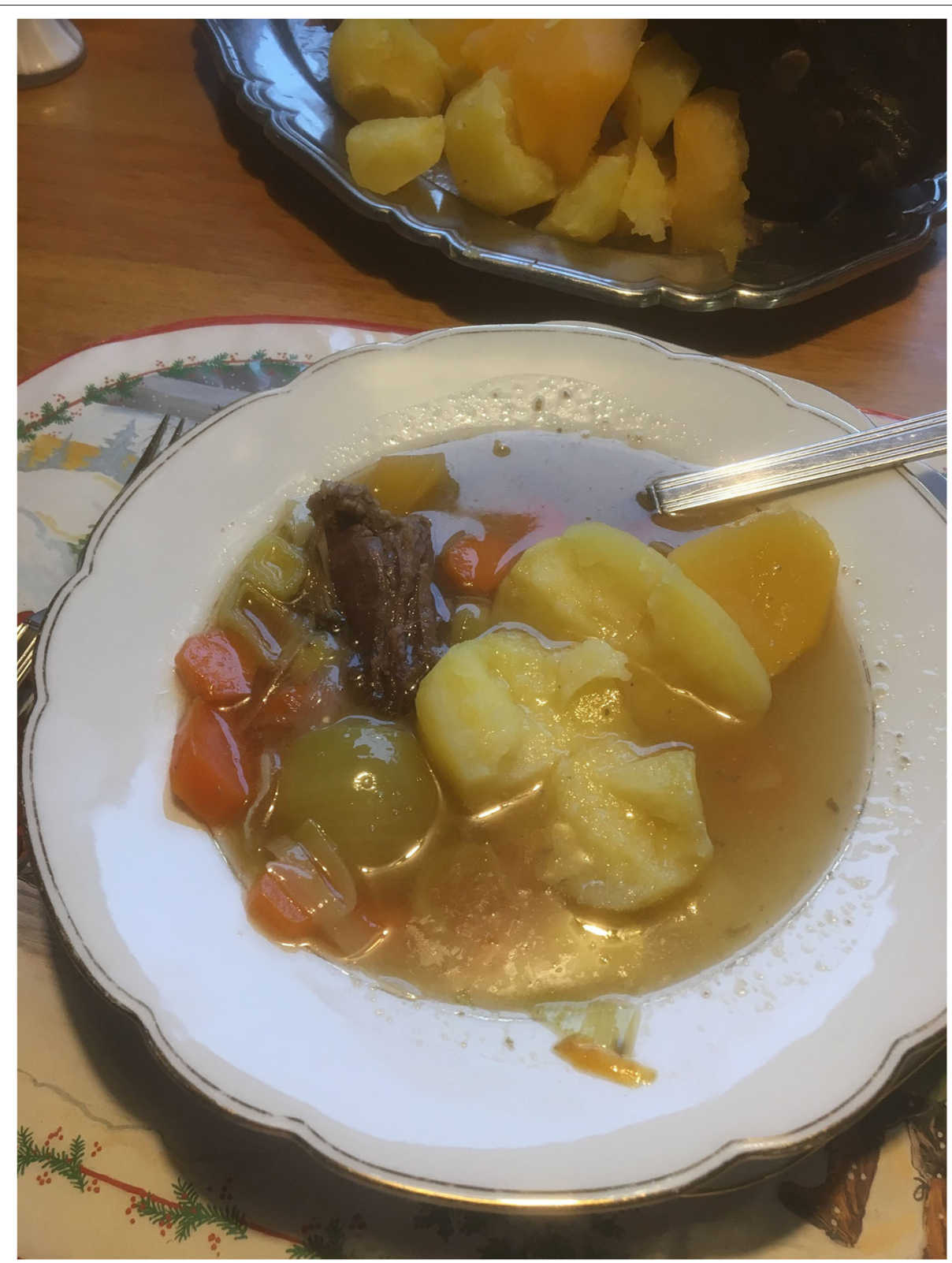

FIGURE 4 | Meat broth is a product made with fat from fermented mutton (ræst kjøt). It is used for soup, súpan, here served with pieces of ræst kjøt, potatoes, and leeks (Photo: Ingvar Svanberg, December 2018).

Covid-19 pandemic, the tourism sector was booming earlier and contributed to the development of many sectors in the society, including foodways (Hagstova Føroya, 2021).

In the Faroes, the grindadráp, the collective drive hunt of pilot whales, is legal, and still important for providing food. There are about 20 towns, villages, or bays across the islands that have the proper conditions and official authorization for beaching whales (Joensen, 2009; Bogadóttir and Olsen, 2017). Ancient customary law regulates the catch. The meat and blubber are distributed free of charge according to an intricate system that involves hunting participants, spectators and for example, elderly people living in the village where the hunt takes place (Joensen, 2009). Since the meat and blubber from whales is highly contaminated, the population is recommended by the health authorities to abstain from eating it (Weihe and Joensen, 2012). However, many people continue to consume whale meat and blubber.

Although sheep farming, which was the main important economic activity until the second half of the nineteenth century, nowadays plays an insignificant role in the economy, it is still of great cultural and social importance (Joensen, 1979, 2015, 2020; Stoklund, 1998). The industrial fisheries, which started in the 1870 s, have also caused changes in the nutritional intake. 


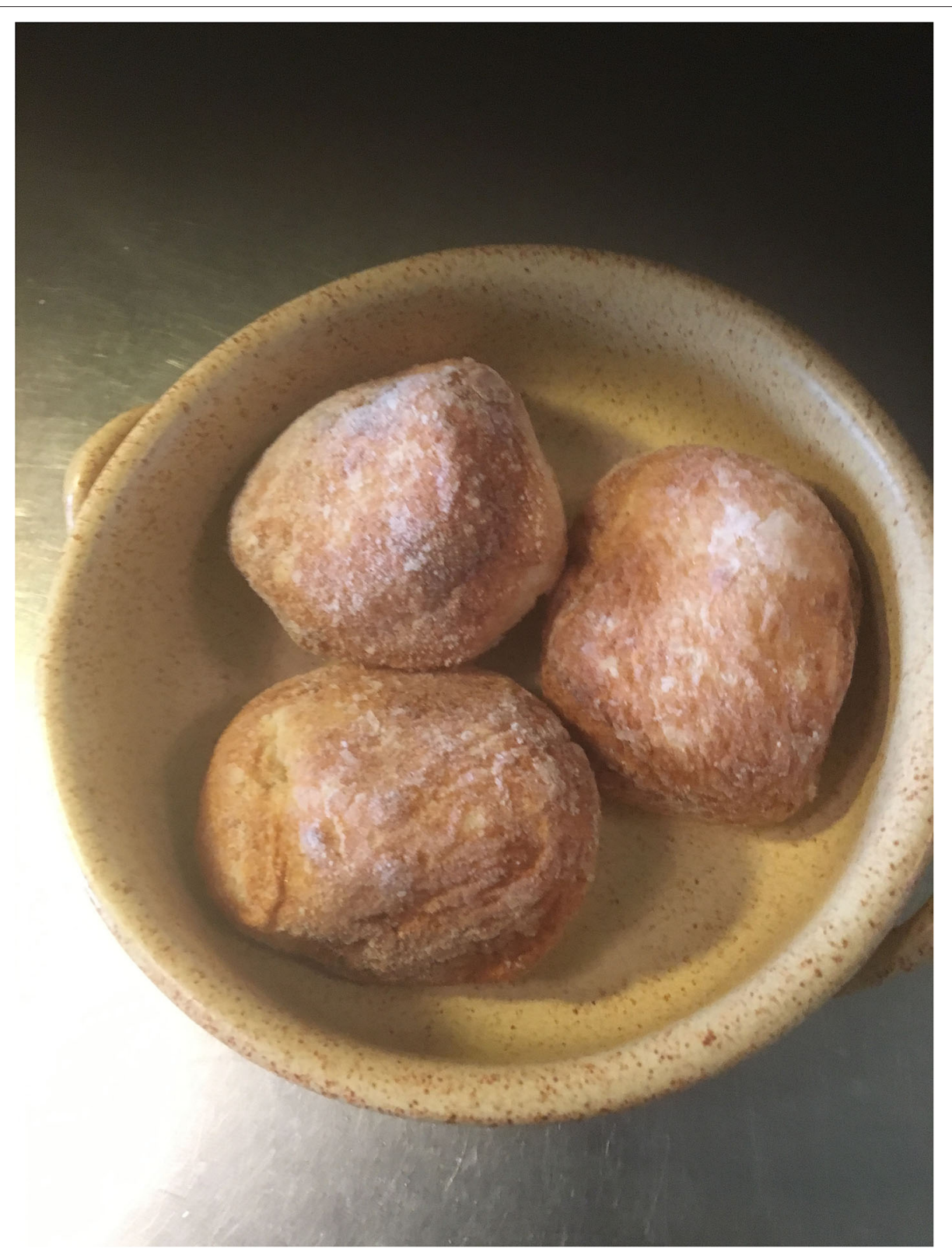

FIGURE 5 | Homemade fiskafrikadellur "a kind of fishcakes" consisting of fileted fish (cod or haddock). It is ground, then mixed with flour, spices and tallow, and finally fried (Photo Ingvar Svanberg 2019).

Farmed salmon, previously unknown, is nowadays considered an integrated ingredient in the Faroese cuisine (Svanberg, 2015).

\section{Fat in Faroese Cuisine}

Traditional foodstuffs and food knowledge play an important role in contemporary Faroese society. Marine and animal fats can be considered the common denominator for the "traditional" Faroese cuisine. Local food artisans, especially women of rural background, are proud of preserving the old ways of preparing Faroese food. Processing raw products and preparing food have always been tasks ascribed to women (Joensen, 1979) (Table 1).
The main fat sources in Faroese cuisine is, and has always been marine based (fish liver, whale blubber, earlier also seal blubber) and animal fat. Tallow and suet from sheep have also played an important role in the local food culture. According to Faroese sheep-owners, several parts of slaughtered sheep containing good tallow may be used for various purposes; the greater and lesser omentum (the membrane surrounding visceral organs), kidney tallow, lump of tallow on the belly, tallow in the pelvis, heart tallow and the important tallow located around the left colon (Joensen, 1979). 


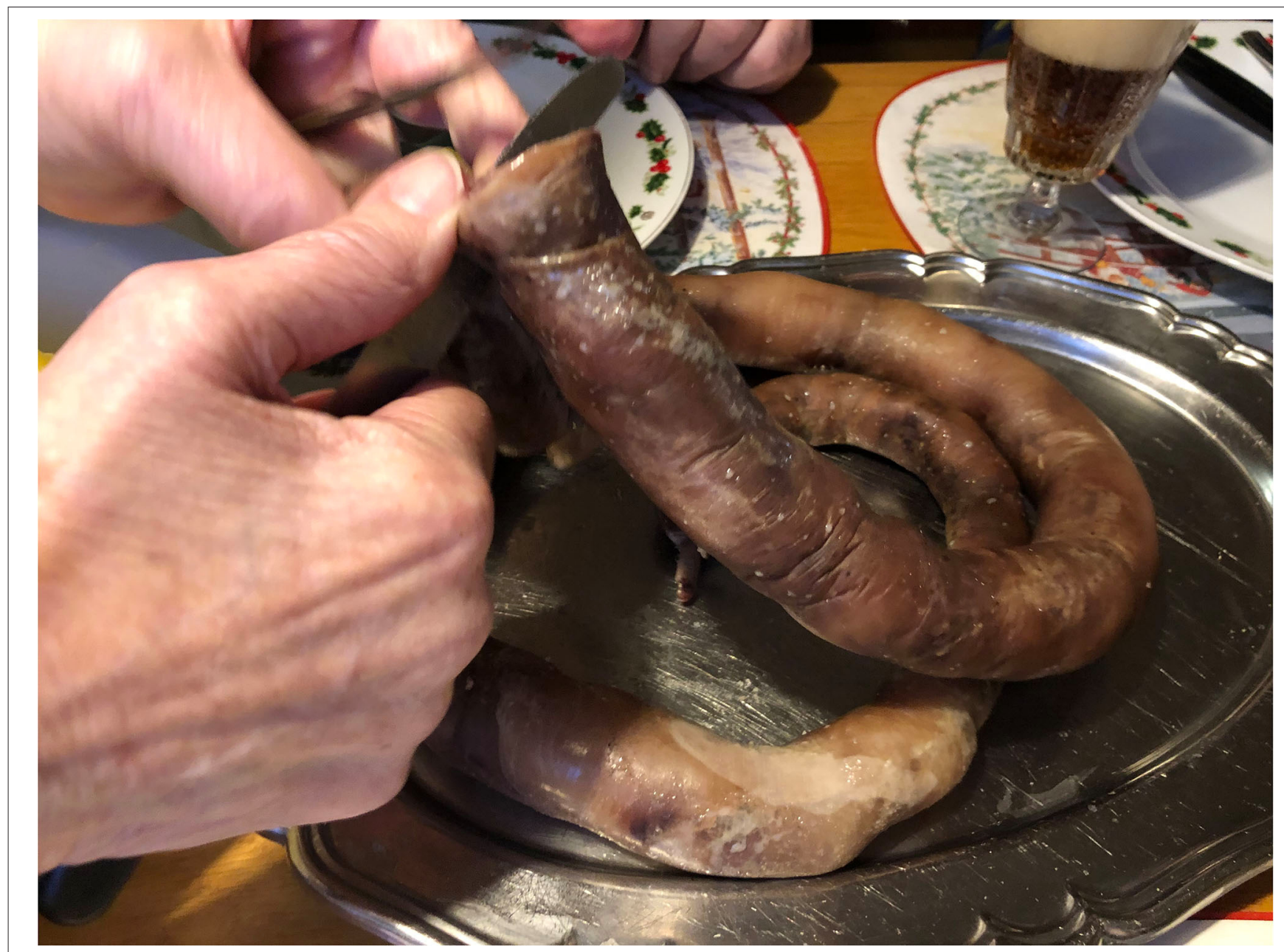

FIGURE 6 | Suðuroyarsperðil-a local kind of sperðil (from Súðuroy) made from sheep’s rectum filled with tallow, pieces of kidney, heart, liver, and meat (Photo Osva Olsen, December 2019).

Taking care of the tallow is generally considered as "women's work" and those who possess this wisdom maintain intricate knowledge of the sheep's anatomy; something, which is, still the case (Joensen, 1979). They know which kind of tallow should be used when preparing various kinds of food. Suet is for example used when making dumplings and fish balls (knetti, frikadellir), black pudding (blóðmørur), and other historically relevant customary foods. Salttálg "salted suet" is an energy rich spread, which is put on bread. Garnatálg is an archaic Faroese foodstuff made with tallow from around the left colon (garnmørur). Intestinal fat is formed into a large oval lump, which is air-dried and eaten. Rognadrýlur is a dish made with dough of barley, boiled roe from cod, and tallow. Nowadays it is eaten with treacle. This is also the case of black pudding, blóðmørur, made with sheep blood, flour and tallow, and at least by some eaten eaten with treacle or brown sugar. Blóðpannukakur "blood pancakes" made with sheep blood, flour, milk and tallow, are popular among children. Tálgapannukakur, pancakes with diced tallow, is another nowadays-rare dish (Joensen, 2015). Many more dishes are made using either sheep suet or tallow (Skaale and Johannesen, 2010).

When preparing garnatálg it is often cut into slices, melted in a pan, and served with roestur fiskur (Svanberg, 2015). Sperðil is a traditional dish made with the tallow around the sheep's rectum, and prepared into a kind of primitive sausage. It can also be used as spread on bread, eaten with fish or as accompaniment to the traditional unleavened bread (drýlur) (Joensen, 1987). It was according to an informant also used for greasing the frying pan when making pancakes or waffles, although it is probably rare today. Earlier, it used to be common to fry sperðil and eat it for breakfast.

Spik, or blubber obtained from the under hide of the pilot whale, is also an important food item. It is usually salted (dry- or brine-salted) and consumed together with dry fish or whale meat. Blubber can also be eaten as a kind of spread on bread. Blubber has always been an important source of Vitamin D (Sørensen et al., 2018). However, today, given the high concentration of polychlorinated biphenyl (PCB) and mercury in the blubber, 


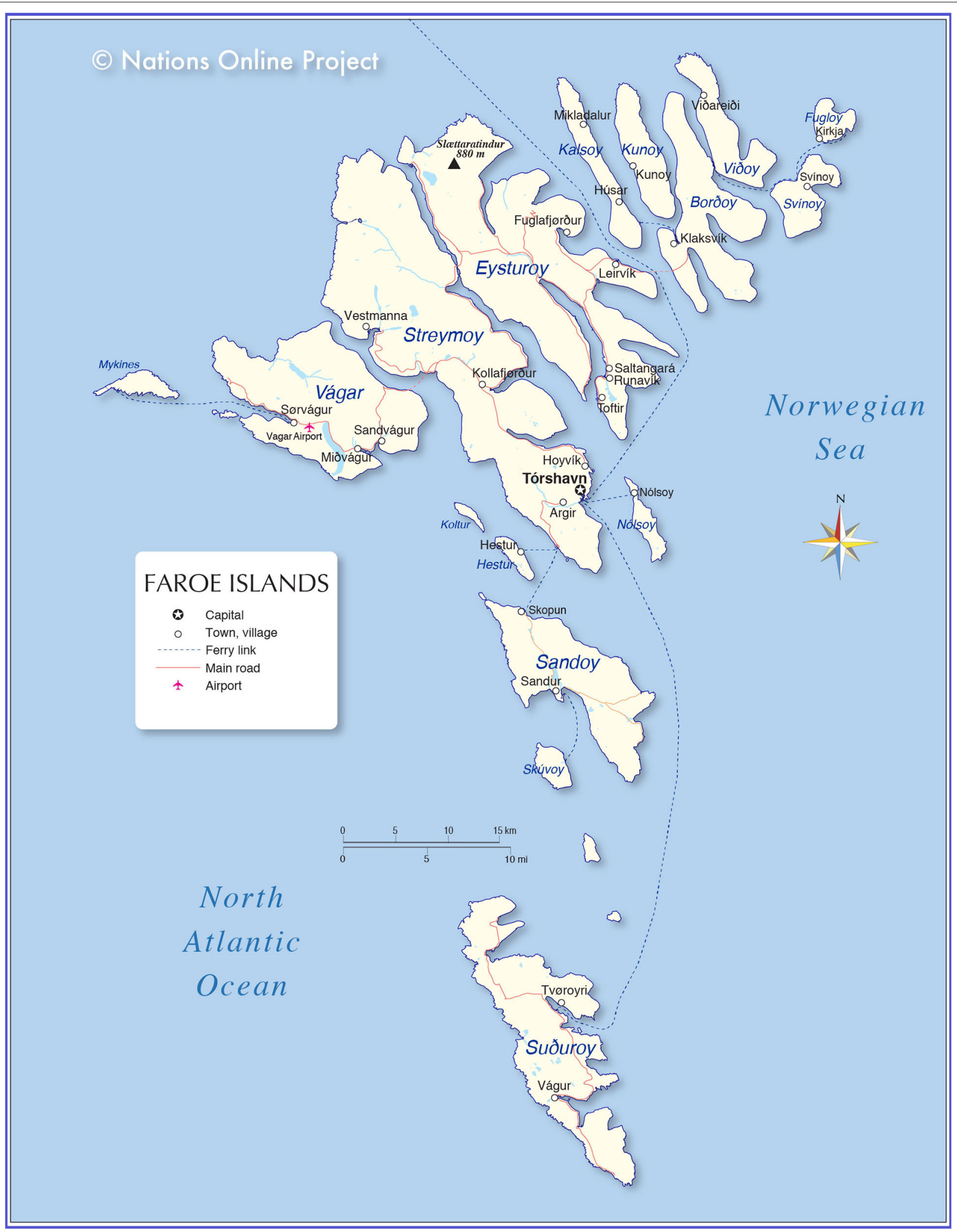

FIGURE 7 | Map of the Faroe Islands (Courtesy Nation Online Project). 


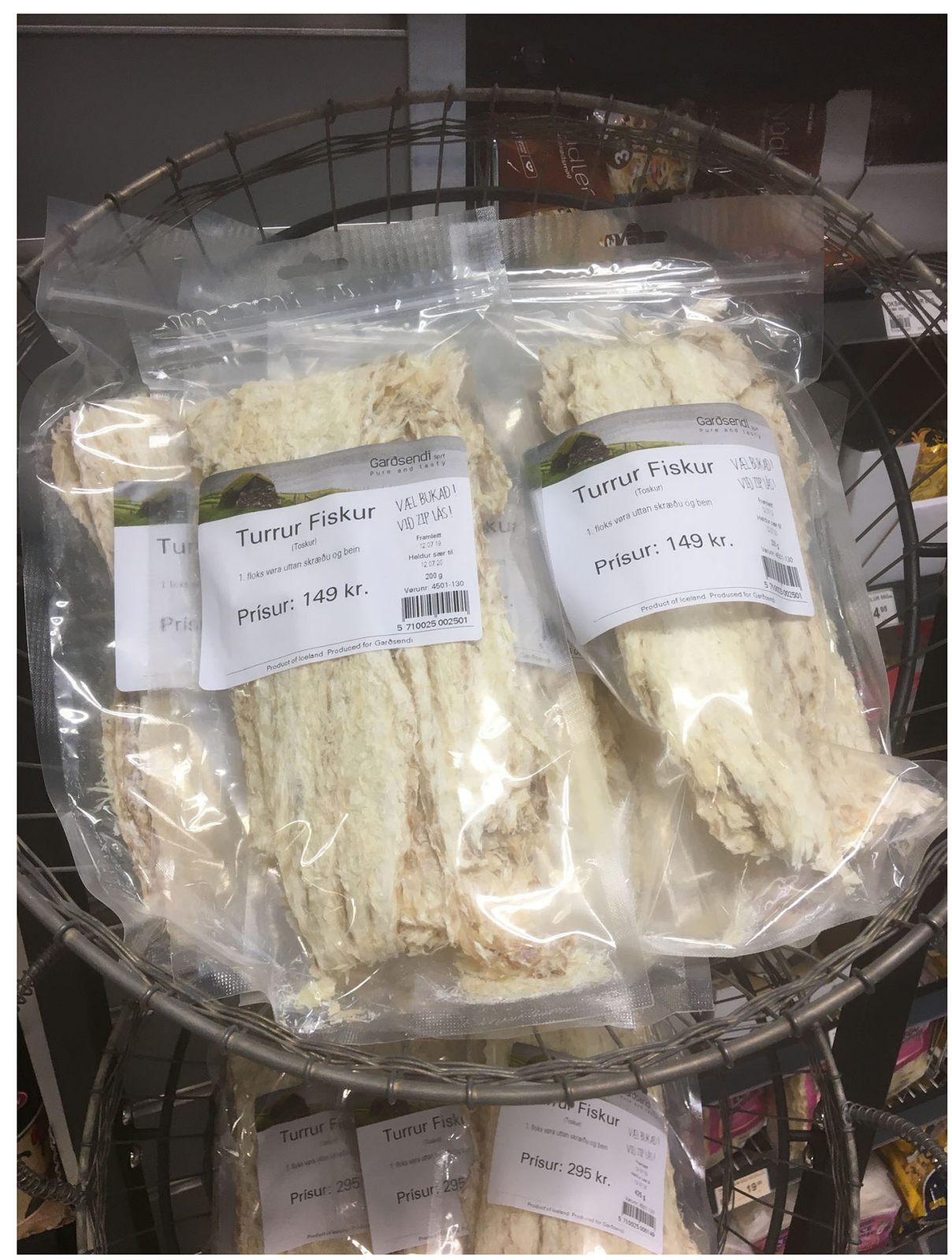

FIGURE 8 | Dried fish (cod) sold in a grocery store in Vestmanna (Photo Ingvar Svanberg, July 2019).

many people try to eat less or even abstain from it altogether. Still, many belonging to the older generation and the so-called "macho Faroese men" continue eating blubber (Svanberg, 2015).

Fiskalivur, "fish liver," from cod, haddock, and saithe, is cooked and eaten with the fish, or popularly used as spread on rye bread, or during earlier times on drýlur. A very ancient dish is kamsur, a kind of dumpling made with fish liver. Livraknetti are knetti made with fish liver rather than tallow. A similar dish is kams- or livurhøvd, cod's head stuffed with fish liver kneaded in flour. Livurkøka was another kind of dumpling that was baked on embers and made from kneaded flour and fish liver. Yet another traditional dish is livurmagi, cod belly stuffed with fish liver (Skylv-Hansen, 1950; Olsson, 1954; Nyman, 1984; Joensen, 2015). Vitamin D has always been supplied through fat fish (Sørensen et al., 2018).

Liver from marine mammals as well as liver from seabirds has had an important place in Faroese traditional food. However, nowadays liver from marine mammals (i.e., whales) is not consumed anymore because of the high concentration of $\mathrm{PCB}$ and mercury (Joensen, 2009). Still, liver from sheep is an important ingredient in a number of Faroese dishes such as livurpylsa, a sausage made with sheep liver and tallow (Olsson, 1954; Joensen, 2015). 
Locally made milk products have played a minor role. Sheep were milked during medieval times, but this activity ended sometime in the 1300s (Arge, 2014). The cattle population on the islands has not had the same cultural significance as the sheep, although they were kept for milk production (Thorsteinsson, 1981; Joensen, 2020). They were kept indoors during the winter. The availability of hay for winter fodder has always been a problem. Therefore, they were kept outdoor from April to the end of November. Milking was traditionally a woman's occupation (Joensen, 1987). Due to climatic and ecological reasons, the lactation period is brief. The milk was precious. The rules of conduct for women who milked were strict (Joensen, 2020). Some coagulated dairy products such as dralvi (thickened milk), fleytir (milk with rennet) and ystingur (curdled milk), were locally produced. Cheese was eaten soon after curdling. In the past decades however, they have lost their importance since now, fermented milk products are readily available in the convenience stores. This applies to other dairy products as well. Cream (rómi) was usually made into butter, but in rare cases mixed with sugar for desserts. Formerly, a popular dish was a kind of junket called rómastampur (Olsson, 1954; Joensen, 2015). An interesting product made of boiled unpasteurized colostrum was a dish known as ketilostur, reminding of the Swedish kalvdans. I have never seen the Faroese kind, since beestings is a rare produce today, but my informants have eaten the ketilostur still in the late 1970s. It was earlier an important gift, especially to households with whom permanent exchange relations were maintained (cf. Joensen, 2020).

Typical Faroese food makes use of gravy and broth in sauce and soup, which is common in the local diet. Meat broth is a fat product, which is made from fermented mutton (Debes, 1673; Olsson, 1954; Joensen, 2015). It is used when preparing soup, súpan, served with potatoes, turnips and some grain (nowadays rice, earlier barley). To have plenty of sauce is important in many traditional meat and fish dishes. Smelt (melted tallow) and margarine, is commonly used as sauce accompanying many fish dishes (Figure 4).

The results of a health and odontology survey conducted in 1937-1938, indicated that the nutritional status of the otherwise poor Faroese villagers mainly subsisting on a traditional fish and meat (including blubber and tallow) diet was adequate from a health perspective (Guðjónsson, 1940). This is further indicated by the fact that the average birth weight at the time was higher than elsewhere in the Nordic countries (Olsen et al., 1995). Mutton and whale meat is rich in carnitine. Something, which is important in a community with a high frequency of Carnitine Transporter Defect (Haraldsdóttir Jensen and Mikkelsen, 2019).

\section{DISCUSSION}

\section{Traditional Foodways and Commensality}

There are several factors that affect the contemporary foodways of the Faroe Islands and the interest for keeping the local diet rich in animal and marine fat (Schulting, 2018). There are historical and social reasons for the conservatism in the diet and foodways. This conservatism was reinforced during Second World War, when about 3,000 islanders were forced to stay in Denmark which was occupied by the Nazi-Germans, and the Faroe Islands were occupied by British trops. When the Faroe islanders in Denmark were allowed to return to their islands in 1945, after 5 years away, traditional local food gained increased popularity as a symbolic and tangible connection to their native homeland and their national identity (Joensen, 1991, Svanberg, 2015). Another factor for maintaining the traditional food is, as mentioned above, the seamen that spend months on commercial fishing vessels, far away from their native islands. Despite the fact that many of them have considerable expendable plenty incomes, they retain traditional values rooted in local village culture. As a result, they have a strong preference for local, traditional food. Homemade food consisting of fermented fish and meat, fish products (e.g., knetti, frikadellur) as well as fat in the form of whale blubber, sheep suet or tallow (including garnatálg) are favorites among them (Svanberg, 2015). Furthermore, the Faroese society is highly family-oriented. Thus, strong familism can be said to be a typical cultural trait. One spends much time with the family and many activities are family-oriented. Huge family gatherings are popular. Equally, commensality that is, for example eating at the same table is an important trait in Faroese social activity and connectivity (Kerner and Chou, 2015) (Figure 5).

The most important rites of passage are christening (baptism), a naming ceremony, that takes place in church when the child is only a few weeks old; confirmation in the Lutheran church when the child is in the early teens; as well as wedding and at funerals. Large feasts involving numerous relatives, friends and neighbors usually follow these church based ceremonies. On these occasions large quantities of food is served (nowadays often buffet-style with many Faroese specialties including wind-dried whale meat, slices of whale blubber, dried fermented mutton, wind-dried goose-meat, dried fish, various types of locally made sausages, etc. (Joensen, 2002).

No socially produced life-styles are immutable. Instead, they are due to various macro factors subject to a process of constant change. Factors such as economy, politics, society, and social structure all have a decisive effect on individuals and local human activities, or what could be labeled cultural pattern (Anderson, 2014). Nowadays it is of course easier than before to have individual food preferences. Some younger people, especially women, tend according to my annotations to avoid fat and often remove fatty parts when consuming for instance mutton. Among some individuals, there are even tendencies toward fat-phobia or anti-fat attitude, that is, fear of consuming fat. In the Faroes, this is a new phenomenon associated with one's own body. However, I do not believe that consumption and knowledge about homemade food is decreasing, as it has in Sweden for instance (Jönsson, 2020). Of course, also in the Faroes large segments of the population have reached the conclusion that excessive intake of fat is harmful to human health and as a result, there is less consumption of fat than before.

Traditional food knowledge and use of resources are always changeable. The increasing globalization with easier access to a wide array of foodstuff has been a determinant factor in changing the local diet (Jönsson, 2020). Also in the Faroes, the food culture has become increasingly internationalized. The 
taste among urbanized locals is therefore gradually changing and becoming uniform with the European norm (Joensen, 2005). For instance, in recent decades the consumption of vegetables has increased while consumption of fish has declined (Joensen, 2015). Fresh and roest mutton remains very popular, while traditional meat and fat products, such as various types of organ meats, whale blubber, and sperðil are decreasing. At the same time, established skills are modified with technical changes, which also makes traditional foods easier to produce. In order to improve the local food crafts, competitions are organized nowadays, to find out for instance, who makes the best garnatálg (Figure 6).

\section{The Importance of Gastrotourism}

Recently tourism has become an important part of the growing economy and now and increasing number of foreign visitors come to the islands during the whole year. A worldwide survey about tourism in 2007 viewed the Faroe Islands as authentic and unspoiled. Many tourists come for bird watching, the beautiful scenery and trekking. Consequently, new hotels have been established and the infrastructure has been improved. Earlier visitors were not mainly attracted to the island for its cuisine and until quite recently so-called food tourism was virtually nonexistent. During the past few years I have also noticed that the number of eating facilities have increased in the rural areas. Still in the 1990s and early 2000s, it was difficult to find places to eat outside the largest settlements, but on a visit in 2019, I saw that the situation had changed dramatically. Now there are plenty of coffee shops and small restaurants all over the Faroes, including fast-food eateries (Svanberg, in press) (Figure 7).

However, this has now changed. Nowadays a number of visitors come to the Faroe Islands as so-called gastro-tourists. It can be defined as activities that provide unique and memorable eating and drinking experiences, both near and far, for the visitors (Povey, 2011; Jönsson, 2020). In recent years, the "New Nordic Cuisine" has attracted international recognition (Nordic Councils of Ministers., 2015). This also applies to the Faroe Islands, where gastro-tourism has become increasingly popular. One reason is the exclusive avant-garde restaurant Koks that has made local food its trademark. In 2017, the restaurant was awarded a Michelin star, and in February 2019, it was awarded a second star. Fermented meat and fish may be difficult to vary in different ways, but Koks has succeeded in transforming traditional craft into modern food (Svanberg, 2015, in press).

In this context, it should be noted that several Faroese food crafts people and food creators have been rewarded with various food awards (i.e., the Nordic Food Awards Embla in various categories such as producers, food artisans etc.). An interesting new sort of food experience for tourists is heimablídni ("home hospitality") where visitors can enjoy dining experiences in people's homes. Here the tourists are treated with locally produced homemade food while being entertained by their hosts with storytelling (Kortesoja et al., 2018).

At a time when industrially produced food is eliminating sensations of taste and smell, fermented products with a distinctive accent has started attracting food-lovers from all over the world (Svanberg, in press). Local fat is part of these dishes. As mentioned earlier, wild plants play a minor role in the traditional local cuisine. However, with regard to these products, an increasing interest may be observed during the last years, especially within the restaurant sector (Svanberg and Ægisson, 2012; Joensen, 2015).

\section{Future of the Traditional Food Knowledge}

Traditional dishes cannot survive in exclusive and trendy restaurants alone. Making use of animal fat from sheep and pilot whales is still mainly a domestic craft. Still, large quantities of the local food (sheep, seabirds, whale meat, blubber) is produced through informal food provision practices (Bogadóttir, 2020). These subsistence practices are a guarantee for the survival of the traditional food knowledge in the Faroes. A real threat to the traditional food knowledge is the increasing preference among the young to eat less healthy, and from a taste-point of view, more smoothed or even tasteless industrial food. This can be juxtaposed with homemade Faroese food, which is rich in flavor and tastes (Sørensen et al., 2018). Roest is regarded as a very specific Faroese taste (Kortesoja et al., 2018).

However, fresh fish is rarely found in the grocery stores and supermarkets. One can come across frozen fish (and dried), but not fresh. Instead, people get the fresh fish (mostly cod) by fishing themselves. They also get it from relatives or artisanal fishermen. It should be noted that a limited quantity of fresh fish is sold occasionally at a small fish market in the west harbor Vestaravág in the center of the Islands' capital town Tórshavn but in fact, the "market" consists of nothing more than a couple of concrete blocks onto which the fish are put on display. Similarly, seafowl and whale meat is not commonly available in the store (Figure 8).

Nevertheless, some of the traditional food is also assumed to affect the health situation of the Faroes. It is believed that the high prevalence of Parkinson's disease in the Faroes stems from consumption of whale meat and blubber (Wermuth et al., 2008).

However, beside these risks, it should be pointed out that most local food is quality food (in contrast to mass-produced convenience, fast or junk food): fish from the surrounding sea, mutton from sheep grazing in the mountains, birds breeding on the cliffs. In addition, it may be that there are certain health benefits involved with eating fermented food.

There is an imminent risk that the next generation will not learn to smell, taste, and touch traditional food anymore. Eating Faroese food is a question of access to healthy and organically produced food. Fermented meat has a high status. It is neither salty nor smoked. Instead, by the process of fermentation it has acquired its own particular taste, which is highly appreciated by both food connoisseurs and most locals. Knowledge is fundamental for maintaining cultural continuity and many locals pride themselves of mastering the Faroese food craft. Recipes for some rare dishes, still made by some families, are nowadays spread through social media. Of course, these days the craftsmanship is subject to rapid change, which can be partly explained by the availability of modern kitchen utensils such as electronic mixers, modern ovens, microwave ovens, etc., which facilitate the work process. Today for example, it has become popular to add new-fangled spices and fresh herbs to the food. Likewise, modern table condiments, such as tomato ketchup, 
HP-sauce, mustard, and remoulade, have become an accepted compliment with traditional Faroese food.

Other challenges to traditional local foodways are modern health trends and ideological food orientations like veganism and vegetarianism that renounce the utilization of animal-based ingredients. Nowadays restaurants are serving vegetable dishes and there are vegan take-a-ways in the capital Tórshavn. For obvious reasons such eating habits are rather impractical in the Faroe Islands. Most ingredients have to be imported. The increased volume of vegetables in the contemporary diet, is however not a "threat" toward the traditional foodways (Joensen, 2015). Today many women refrain from eating whale blubber and sometimes avoid visible fat since it is deemed health hazardous (Weihe and Joensen, 2012). However, despite the fact that it is considered unhealthy to consume whale blubber, the older generation, representatives for rural families and what social anthropologist calls "macho Faroese men," continue eating blubber (Svanberg, 2015).

\section{CONCLUSION}

This study has discussed the past, present, and the potential future status of animal and marine fat in the Faroese diet. As we have seen, eating is not only a biological necessity; it also involves cultural, economic, and social activities. Today, especially the elderly generation continues consuming a rural diet based on fish and meat. Many locals are proud that several aspects of their food tradition have been preserved. The islanders themselves produce significant quantities of traditional food items. In particular, the Faroese enjoy the strong flavors of air-dried fermented fish and mutton. In addition, whale blubber and sheep tallow still constitute important parts of the local diet.

Many people on the islands prefer to prepare traditional dishes themselves at home, and the traditional artisan craft knowledge about food is widely spread. Although, industrial modes of preparing local products cannot replace traditional food knowledge some technical advances has made the craft easier and quicker to carry out. However, the possibility that oldfashioned recipes and dishes will survive or not mainly depends on the maintenance of customary food knowledge. Some of the traditional foodstuff as locally produced roestur fiskur, frikadellur, knetti and garnatálg can be bought in the grocery stores. Canned salted fish roe is also available in the stores. It is a popular spread on bread. Urban people and professionals can still enjoy the Faroese cuisine based on fish and tallow.

Just as in other parts of Europe, the daily diet has recently gone through profound changes, partly explained by such

\section{REFERENCES}

Adams, V., Burke, N. J., and Whitmarsh, I. (2014). Slow research. Med. Anthropol. 33, 179-197. doi: 10.1080/01459740.2013.858335

Anderson, E. N. (2014). Everyone Eats. Understanding Food and Culture. New York, NY: NYU Press.

Arge, S. V. (1995). Mergsogin bein: ein aldargamal matsiður. Fróðskaparrit $43,59-65$. external factors as closer integration into the world economy, overall modernization and improved household economy. As a consequence, there is a richer variety in products available on the islands than before. Today, grocery stores scattered across the islands offer a rich variety of foodstuffs, among them many imported. However, especially men persevere in adhering to "genuine" Faroese food. In contrast, young women appear to be more susceptible to new trends, including foodways, and thus to a higher degree embrace modern ingredients and cooking techniques in their everyday life.

However, as long as traditional subsistence with fishing, sheep husbandry, whale hunting and some fowling, continue to constitute important elements in local food production, it is also likely that fat and meat will persist in being an important part of the local diet in the Faroes. The traditional food knowledge inherited from bygone times will continue to be part of Faroese culture and symbols of identity.

\section{DATA AVAILABILITY STATEMENT}

The original contributions presented in the study are included in the article/supplementary material, further inquiries can be directed to the corresponding author/s.

\section{ETHICS STATEMENT}

Ethical review and approval was not required for the study on human participants in accordance with the local legislation and institutional requirements. Written informed consent for participation was not required for this study in accordance with the national legislation and the institutional requirements.

\section{AUTHOR CONTRIBUTIONS}

The author confirms being the sole contributor of this work and has approved it for publication.

\section{ACKNOWLEDGMENTS}

IS thanks especially to the Olsen family in Vestmanna who through the years have taught me all there is to know about Faroese foodways. Thanks also to the three reviewers for their constructive comments, which helped me to improve the manuscript. IS also want to express his gratitudes to Osva Olsen (Uppsala), Navarana Ingvarsdóttir Olsen (Tórshavn), Patrick Hällzon (Stockholm), Alison Locker (Andorra), and Lena Lubenow (Uppsala).
Arge, S. V. (2005). “Um svínahald í Føroyum,” in Fólkaleikur: Heiðursrit til Jóan Paula Joensen, ed. A. Mortensen (Tórshavn: Føroya Fróðskaparfelag), 38-52.

Arge, S. V. (2014). Viking faroes: settlement, paleoeconomy, and chronology. J. North Atlantic 7, 1-17. doi: 10.3721/037. 002.sp701

Arge, S. V., Church, M. J., and Brewington, S. D. (2009). Pigs in the Faroe Islands: an ancient facet of the islands' paleoeconomy. J. North Atlantic 2, 19-32. doi: 10.3721/037.002.0104 
Bloch, D., Dam, M., and Hanusardóttir, M. (2003). "Marine mammals as meat sources," in Encyclopedia of Food Sciences and Nutrition, eds. B. Caballero, P. Finglas, and F. Toldrav (London: Academic Press), 3733-3739. doi: 10.1016/B0-12-227055-X/00 744-6

Bloch, D., and Mikkelsen, B. (2009). Catch history and distribution of whitesided dolphin (Lagenorhynchus acutus) of the Faroe Islands. Fródskaparrit 57, 190-198. doi: 10.18602/fsj.v57i0.82

Bogadóttir, R. (2020). The social metabolism of quiet sustainability in the Faroe Islands. Sustainability 12:735. doi: 10.3390/su12020735

Bogadóttir, R., and Olsen, E. S. (2017). Making degrowth locally meaningsful: the case of the Faroese grindadráp. J. Political Ecol. 24, 504-518. doi: $10.2458 / \mathrm{v} 24 \mathrm{i} 1.20888$

Church, M. J., Arge, S. V., Edwards, K. J., Ascough, P. L., Bond, J. M., Cook, G. T., et al. (2013). The Vikings were not the first colonizers of the Faroe Islands. Quat. Sci. Rev. 77, 228-232. doi: 10.1016/j.quascirev.2013.06.011

Claussøn Friis, P. (1632). Norriges oc omliggende Øers sandfordige Bescriffuelse Kiøbenhaffn: Melchior Martzan.

Dalgård, C., Petersen, M. S., Schmedes, A. V., and Brandslund, I. (2010). High latitude and marine diet: vitamin D status in elderly Faroese. Br. J. Nutrit. 104, 914-918. doi: 10.1017/S0007114510001509

Dalsgaard, S. (2002). Maturin. Vørukunnleiki. Tórshavn: Føroya Skúlaboksgrunnur.

Debes, L. J. (1673). Foroce et Foroa reserata, det er Forøenis o forrøiske Indbyggeres Beskrifvelse. Kiøbenhafn: Matthias Jørgensen.

Eidlitz, K. (1969). Food and Emergency Food in the Circumpolar Area. Uppsala: Almqvist \& Wiksell.

Fjellström, P. (1982). "Diet in the Nordic countries in olden times," in Symposium on Dental Health and Nutrition in the Nordic Sparsely Populated Areas (Oulo: Nordic Council for Arctic Medical Research), 7-13.

Guðjónsson, S. V. (1940). P. Carl Petersens Fonds Ernoeringsexpedition til Ferøerne 1936-37. Købehavn: Arnold Busch.

Guttesen, R. (2001). Plant production on a Faeroese farm 1813-1892, related to climatic fluctuations. Geografisk Tidsskrift-Danish J. Geography 101, 67-76. doi: 10.1080/00167223.2001.1064 9451

Håseth, T. T., Thorkelsson, G., and Sidhu, M. (2015). "North European Products," in Handbook of Fermented Meat and Poultry, ed. J. Toldrá (Chichester: Wiley-Blackwell), 407-413. doi: 10.1002/9780470376430. ch39

Hagstova Føroya (2021). Statistics Faroe Islands. Available online at: http://www. hagstova.fo/en (accessed January 26, 2021).

Hannon, G. E., Arge, S. V., Fosaa, A.-M., Mahler, D. L., Olsen, B., and Bradshaw, R. H. W. (2009). "Faroe Islands," in: Encyclopedia of Islands, eds. R. G. Gillespie and D. A. Clague (Oakland, CA: University of California Press), 291-297.

Haraldsdóttir Jensen, H., and Mikkelsen, B. (2019). Karnitin í tvøsti og lambskjøti. Fróðskaparrit 65-66, 1-9. doi: 10.18602/fsj.v0i0.116

Henriksen, J. (2004). Góðaráð. Tórshavn: Forlagið Góðaráð.

Hermann, B., Persson, H., Jensen, J.-K., Joensen, H. D., Klint, M., and Olsen, B. (2006). Chlamydophila psittaci in fulmars, the Faroe Islands. Emerg. Infect. Dis. 12, 330-332. doi: 10.3201/eid1202.050404

Joensen, J. P. (1982). "Man and the physical environment," in The Physical Environment of the Faroe Islands, ed. G. K. Rutherford (The Hague: Dr W. Junk Publishers), 125-141. doi: 10.1007/978-94-009-7977-2_9

Joensen, J. P. (1987). Fólk og mentan. Tórshavn: Føroya Skúlabókagrunnur.

Joensen, J. P. (1991). At finna ella uppfinna tað føroyska. Fróðskaparrit $36-37,28-38$.

Joensen, J. P. (2002). I ærlige Brudefolk. Bryllup på Færøerne. København: Museum Tusculanums Forlag.

Joensen, J. P. (2005) “Nye og traditionelle træk i færøsk madkultur”, in Nye og traditionelle trekk i nordisk matkultur, ed. E. Fossgard (Voss: Vestnorsk kulturakademi), 59-71.

Joensen, J. P. (2009). Pilot Whaling in the Faroe Islands. History - Ethnography Symbol. Tórshavn: Faroe University Press.

Joensen, J. P. (2015). Bót og Biti: Matur og Matarhald i Føroyum. vol. 1-2. Tórshavn: Faroe University Press.

Joensen, J. P. (2020). Ketilostur, Maðurin umborð og Putursukurveðrar: Tríggjar Smáar Ritgerðir. Vestmanna: Sprotin.
Joensen, R. (1979). Fåreavl på Færøerne. København: Reitzel.

Johansson, E. (1994). Skogarnas Fria Söner: Maskulinitet och Modernitet $i$ Norrländskt Skogsarbete. Stockholm: Nordiska Museet.

Jönsson, H. (2020). Svensk Måltidskultur. Stockholm: Carlssons.

Kawulich, B. B. (2005). Participant observation as a data collection method. Forum 6:43. doi: 10.17169/fqs-6.s.466

Kerner, S., and Chou, C. (2015). "Introduction," in Commensality: From Everyday Food to Feast, eds. S. Kerner, C. Chou, and M. Warmind. (London: Bloomsbury Academic), 1-9. doi: 10.5040/9781474245326.ch-001

Knudsen, K. J. L. (2010). Language use and linguistic nationalism in the Faroe Islands. language use and linguistic nationalism in the Faroe Islands. Int. J. Multilingualism 7, 128-146. doi: 10.1080/14790710903518404

Kortesoja, A., Bröckl, M., Jönsson, H., Kontiokari, V., and Halonen,. M. (2018). Nordic Best Practices Relevant for UNEP 10YFP on Sustainable Buildings \& Construction and Sustainable Food Systems. (TemaNord 2018:505). Copenhagen: Nordic Council of Ministers. doi: 10.6027/TN2018-505

Kuhnlein, H. V., and Chan, H. M. (2000). Traditional food systems of northern indigenous people. Аnnu. Rev. Nutr. 20, 595-626. doi: 10.1146/annurev.nutr.20.1.595

Larsson, G., and Svanberg, I. (2009). "The Faroe Islands and Iceland"” in Islam in the Nordic and Baltic Countries, ed. G. Larsson (London: Routledge), 8-17. doi: $10.4324 / 9780203879115$

Lauer, K. (1989). Dietary changes in temporal relation to multiple sclerosis in the Faroe Islands: an evaluation of Literary Sources. Neuroepidemiology 8, 200-206. doi: $10.1159 / 000110183$

McElroy, A., and Townsend, P. K. (2015). Medical Anthropology in Ecological Perspective. New York, NY: Westview Press.

Nordic Councils of Ministers. (2015). The Emergence of a New Nordic Food Culture: Final report from the program New Nordic Food II, 2010-2014. Copehagen: Nordic Councils of Ministers. doi: 10.6027/ANP2015-723

Nørrevang, A. (1986). Traditions of sea bird fowling in the Faroes: An ecological basis for sustained fowling. Ornis Scand. 17, 275-281. doi: 10.2307/3676838

Nyman, Å. (1984). Knettir, klåbb, kams och palt. Nordskandinavisk etnologi 3, 83-98.

Nyman, A. (1958). Hay harvesting methods on the Faroe Islands. Folk-Liv 21-22, 101-106.

O'Keefe, S. F. (2000). “Animal, marine and vegetable oils," in The Cambridge World History of Food. Vol. 1, eds K. F. Kiple and K. Coneè Ornelas (Cambridge: Cambridge University Press), 375-387.

Olsen, S. F., Hansen, H. S., Secher, N. J., Jensen, B., and Sandström, B. (1995). Gestation length and birth weight in relation to intake of marine n-3 fatty acids. Br. J. Nutrit. 73, 397-404. doi: 10.1079/BJN19950042

Olsson, A. (1952). Field Notes From the Faroe Islands, July-August 1952. Göteborg: Museum of Gothenburg.

Olsson, A. (1954). Färöiska kostvanor. Rig 37, 79-91.

Olsson, A. (1958). Om Allmogens Kosthåll. Studier med utgångspunkt från västnordiska matvanor. Lund: Gleerups.

Panum, P. L. (1847). Iakttagelser, anstillede under Mæslingeepidemien paa Færøerne i Aaret 1846. Bibliothek Loger 1, 270-340.

Peloquin, C., and Berkes, F. (2009). Local knowledge, subsistence harvests, and social-ecological complexity in James Bay. Hum. Ecol. 37, 533-545. doi: 10.1007/s10745-009-9255-0

Pieroni, A., Pawera, L., and Shah, G. M. (2016). "Gastronomic ethnobiology," in Introduction to Ethnobiology, eds. U. P. Albuquerque and R. R. N. Rômulo Alves (Cham: Springer Press), 53-62. doi: 10.1007/978-3-319-28 155-1_9

Povey, G. (2011). "Gastronomy and tourism," in Research Themes for Tourism, eds. P. Robinson, S. Heitmann and P.U.C. Dieke. (Wallingford, CT: CAB International), 233-248. doi: 10.1079/9781845936846.0233

Rasmussen, H. (1957). "Der pfluglose Feldbau auf den Färöer," in Agrarethnographie : Vorträge der Berliner Tagung vom 29. Sept. bis 1. Okt. 1955 (Berlin: Akademie-Verlag), 68-80.

Rasmussen, H. (1971). Die Nahrungsforschung auf den Färöer. Ethnol. Euro. 5, 49-52. doi: 10.16995/ee.3242

Schulting, R. (2018). "Hunter-gatherer diet, subsistence and foodways," in The Oxford Handbook of the Archaeology and Anthropology of Hunter-Gatherers, eds. V. Cummings, P. Jordan, and M. Zvelebil (Oxford: Oxford University Press), 1266-1287. 
Skaale, Ó., and Johannesen, M. (2010). Matur og matgerð. 6th ed. Tórshavn: Grønalið.

Skylv-Hansen, J. M. (1950). Gamlar Gøtur. Tórshavn: Varðin.

Sørensen, S., Markedal, K. E., and Sørensen, J. C. (2018). "Food, nutrition, and health in Denmark (including Greenland and Faroe Islands)," in Nutritional and Health Aspects of Traditional and Ethnic Foods of Nordic Countries, eds. V. Andersen, E. Bar, and G. Wirtanen (Amsterdam: Elsevier), 99-125. doi: 10.1016/B978-0-12-809416-7.00004-4

Stoklund, B. (1984). "Building traditions in the Northern World," in The Northern and Western Isles in the Viking World, eds. A. Fenton and H. Pálsson (Edinburgh: John Donald Publishers), 96-223.

Stoklund, B. (1998), Á fjall in the Faroe Islands. Scottish Stud. 32, 89-106.

Svabo, J. C. (1959). Indberetninger fra en Reise i Forø 1781 og 1782. København: Selskabet til udgivelse af Færøske kildeskrifter og studier.

Svabo, J. C. (1966), Dictionarium Foroense 1. Ordbogen. Købehavn: Munksgaard.

Svanberg, I. (1998). The use of wild plants in the Faroe Islands 1590-1990. Svenska Linnésällskapets Årsskrift 1996-1997, 81-130.

Svanberg, I. (2001). The snow bunting (Plectrophenax nivalis) as food in the northern circumpolar region. Fróðskaparrit 48, 29-40.

Svanberg, I. (2015). Ræstur fiskur: air-dried fermented fish the Faroese way. J. Ethnobio. Ethnomed. 76, 1-14. doi: 10.1186/s13002-015-0064-9

Svanberg, I. (in press). "Faroe Islands," in Europe: An Encyclopedia of Culture and Society, Vol. 1, ed. T. M. Wilson (Santa Barbara, CA: ABC-CLIO).

Svanberg, I., and Ægisson, S. (2006). Black guillemot (Cepphus grylle) in circumpolar folk ornithology. Scripta Island. 56, 101-114.

Svanberg, I., and Ægisson, S. (2012). Edible wild plant use in the Faroe Islands and Iceland. Acta Soc. Botanicorum Poloniae 81, 233-238. doi: $10.5586 /$ asbp. 2012.035

Sydow, C. W. (1948). Selected Papers on Folklore. Copenhagen: Rosenkilde and Bagger.

Taylor, D. W., and Anderson, G. J. (2020). Culinary cultural conservation and cultural keystone food groups: concepts in ethnobotany. Human Ecol. 48, 189-198. doi: 10.1007/s10745-020-00137-5
Teuteberg, H. J. (1986). "Periods and turning-points in the history of European diet: a preliminary outline of problems and methods," in Food in Change: Eating Habits from the Middle Ages to the Present Day, eds. A. Fenton and E. Kisban (Edinburgh: John Donald Publishers), 11-23.

Thorsteinsson, A. (1981). Jordforhold i det gamle landbrugssamfund. Landsinspektøren 30, 664-678.

Trevelyan, W. C. (1853). Faroe Islands. Edinburgh New Philos. J. 54:380.

Wang, H., Jensen, J. K., Olsson, A., Varimore, F., Aazix, R., Guy, L., et al. (2020). Chlamydia psittaci in fulmars on the Faroe Islands: a causative link to South American psittacines eight decades after a severe epidemic. Microb. Infect. 22, 356-359. doi: 10.1016/j.micinf.2020.0 2.007

Weihe, P., and Joensen, H. D. (2012). Dietary recommendations regarding pilot whale meat and blubber in the Faroe Islands. Int. J. Circumpolar Health 71:18594. doi: 10.3402/ijch.v71i0.1 8594

Wermuth, L., Bech, S., Skaale Petersen, M., Joensen, P., Weihe, P., and Grandjean, P. (2008). Prevalence and incidence of Parkinson's disease in The Faroe Islands. Acta Neurol. Scand. 118, 126-131. doi: 10.1111/j.1600-0404.2007. 00991.x

Young, G. V. C. (1979). From the Vikings to the Reformation: A Chronicle of the Faroe Islands up to 1538. Douglas: Shearwater Press.

Conflict of Interest: The author declares that the research was conducted in the absence of any commercial or financial relationships that could be construed as a potential conflict of interest.

Copyright (C) 2021 Svanberg. This is an open-access article distributed under the terms of the Creative Commons Attribution License (CC BY). The use, distribution or reproduction in other forums is permitted, provided the original author(s) and the copyright owner(s) are credited and that the original publication in this journal is cited, in accordance with accepted academic practice. No use, distribution or reproduction is permitted which does not comply with these terms. 